\title{
EFFECT OF THE BLASTOCYST ON A UTERINE AMINO ACID ARYLAMIDASE IN THE RABBIT
}

\author{
GERHILD VAN HOORN AND H.-W. DENKER* \\ Max-Planck-Institut für Immunbiologie, D-78 Freiburg, West Germany
}

(Received 18th February 1975)

The activity of a leucine- $\beta$-naphthylamide-splitting enzyme has been shown histochemically to increase markedly before implantation and to reach a sharp peak at 5-6 days post coitum (p.c.) (Denker, 1969; see also description of unmated and 6 days p.c. stages by Petry et al., 1970). The enzyme has been referred to as 'leucine aminopeptidase'. Recently, however, it has become customary to call this class of enzymes 'amino acid arylamidases' or 'amino acid naphthylamidases', because they exhibit properties which differ from those of classical leucine aminopeptidase (cytosol aminopeptidase, EG 3.4.11.1). Amino acid arylamidases are more related to EC 3.4.11.2, but definitive classification is still lacking (see Patterson et al., 1963; for discussion and recent references see Bergmeyer, 1974; Pearse, 1972; Denker \& Stangl, 1974).

In the present study the activity of the enzyme at and between the implantation sites was compared.

The rabbits used were of mixed breeds. Each female was mated to two fertile bucks. Pseudopregnancy was induced by mating with vasectomized males. The animals were killed by stunning and exsanguinating, and the uteri were quickly removed.

For the biochemical tests, nine virgin female rabbits, 11-17 months old and weighing $3.0-4.3 \mathrm{~kg}$, were used. After removing the uteri, all subsequent procedures were performed at $0-8^{\circ} \mathrm{C}$, and precooled solutions were used. The uteri of rabbits killed at $6 \frac{2}{3}$ days p.c. were cut into pieces containing one blastocyst each, and the blastocysts were removed by flushing with about $2.5 \mathrm{ml} 0.9 \%$ $\mathrm{NaCl}$ solution. The uteri of rabbits killed at 8 days p.c., i.e. after antimesometrial implantation, were not flushed but the blastocyst fluid was aspirated by a hypodermic needle. Immediately after flushing or puncture, the visible blastocyst sites of the uterus were separated from the interblastocyst areas. All uterine segments were then opened along the antimesometrial side and flattened. The endometrial tissues were carefully cut off with curved scissors, and all the blastocyst sites of a uterus were combined and frozen in sealed plastic bags in liquid nitrogen. The interblastocyst endometrial areas were similarly combined and frozen. The uteri of 8-day pseudopregnant females were flushed with $\mathrm{NaCl}$ solution and the endometrium treated similarly.

The material was homogenized for $2 \frac{1}{2} \mathrm{~min}$ at $1000 \mathrm{rev} / \mathrm{min}$ in an ice-cooled teflon-glass Potter homogenizer. The homogenate was diluted tenfold $(w / v)$

* Reprint requests to: Dr H.-W. Denker, Abteilung Anatomie der RWTH, Melatener Strasse 211, D-51 Aachen, West Germany. 


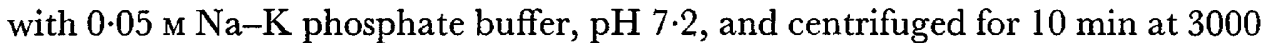
g at $4^{\circ} \mathrm{C}$. Enzyme activity was determined using $0.025 \mathrm{ml}$ supernatant in $2.0 \mathrm{ml}$ (end volume) veronal-acetate Michaelis buffer, $\mathrm{pH} 7 \cdot 0$, with $7 \cdot 7 \times 10^{-4} \mathrm{M}$-Lleucine- $\beta$-naphthylamide as substrate, and an incubation period of $30 \mathrm{~min}$ at $37^{\circ} \mathrm{C}$. The liberated $\beta$-naphthylamine was determined by the GoldbargRutenburg type Bratton-Marshall reaction as modified by Schmidt (1963). Some material was preincubated for $30 \mathrm{~min}$ at $37^{\circ} \mathrm{C}$ in the same buffer which contained $10^{-3} \mathrm{M} \mathrm{CoCl}_{2}$; this concentration of ions was then also maintained during incubation. For the calibration curve, $\beta$-naphthylamine- $\mathrm{HCl}$ was used. The protein content of the samples was determined by the biuret method of Westley \& Lambeth (1960). All protein determinations were run in duplicate, and crystalline bovine serum albumin was used for calibration.

For the histochemical tests, twenty virgin females, 8-17 months old and weighing $3.0-4.2 \mathrm{~kg}$, were used. At least two animals were killed to represent each of the stages of $5,6,6 \frac{2}{3}, 7,7 \frac{1}{3}$ and 8 days p.c. Pieces of uteri were quenched with liquid nitrogen and cut longitudinally on a cryostat at $-25^{\circ} \mathrm{C}$ and at a thickness of $14 \mu \mathrm{m}$. From each piece, two sets of sections were taken. One set was mounted and processed in the fresh state according to the method described by Nachlas et al. (see Pearse, 1972). The other set was freeze-substituted according to the method of Glenner (1962) and incubated similarly except that Fast Garnet GBC was used as coupler. The diazonium salts and bovine serum albumin were obtained from Serva (Heidelberg). The other chemicals were reagent grade.

In the biochemical tests, the arylamidase activity in the endometrium was, at $6 \frac{2}{3}$ days p.c., $34 \cdot 8 \pm 1 \cdot 3$ (S.E.) between the blastocysts compared with $24.0 \pm 2.9$ $\mathrm{mU} / \mathrm{mg}$ protein at the sites of the blastocysts (four uteri from two rabbits). At 8 days the endometrial activity between the blastocysts was $43.3 \pm 5.5$ compared with $18.4 \pm 2.5 \mathrm{mU} / \mathrm{mg}$ protein at the sites of the blastocysts (four uteri from two rabbits). In both stages, essentially the same differences were found with and without $\mathrm{Co}^{++}$-activation. In another six uteri from three rabbits at 8 days p.c. the activity of the endometrium between the blastocysts after flushing was $40.3 \pm$ $4.8 \mathrm{mU} / \mathrm{mg}$ protein. In two uteri from two 8-day pseudopregnant does the activity was 40.3 (range: 2.6 ) $\mathrm{mU} / \mathrm{mg}$ protein.

In the histochemical tests, the freeze-substituted sections gave a more precise localization than did native sections (see Plates 1 and 2), and uterine secretion was retained in the former but not in the latter (Denker \& Stangl, 1974). With

\section{EXPLANATION OF PLATE 1}

Fic. 1. Freeze-substituted section of the endometrium and blastocyst of a rabbit 5 days p.c. showing strong arylamidase activity in all parts of uterine epithelium. Note the reaction of the uterine secretion accumulated near the blastocyst $(S) . \times 30$.

FIg. 2. Native section of the uterus and blastocyst at 7 days p.c. Uterine epithelium at the mesometrial part of the blastocyst site (B) is slightly less reactive than in the interblastocyst areas $(\mathrm{I}) . \times 13$.

FIG. 3. Native section of the uterus and blastocyst at 8 days p.c. The mesometrial endometrium, the developing maternal part of the placenta at the blastocyst site (B), is nearly unreactive in contrast to the positively reacting interconceptual areas (I) which appear to be more deeply stained than those shown in Fig. 2 because of the photographic technique. $\times 10$. 
PLATE 1

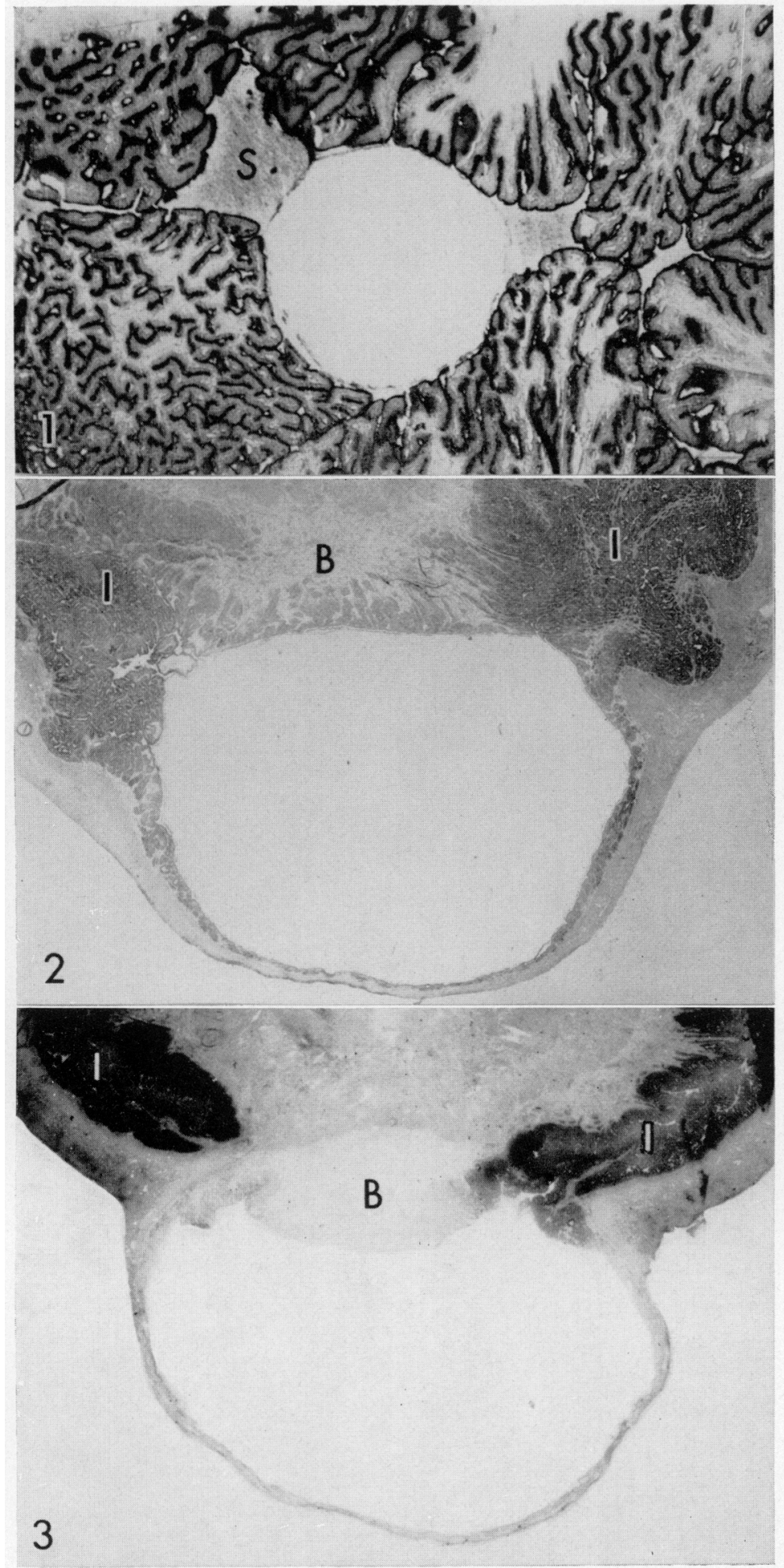

(Facing p. 360) 
PLATE 2
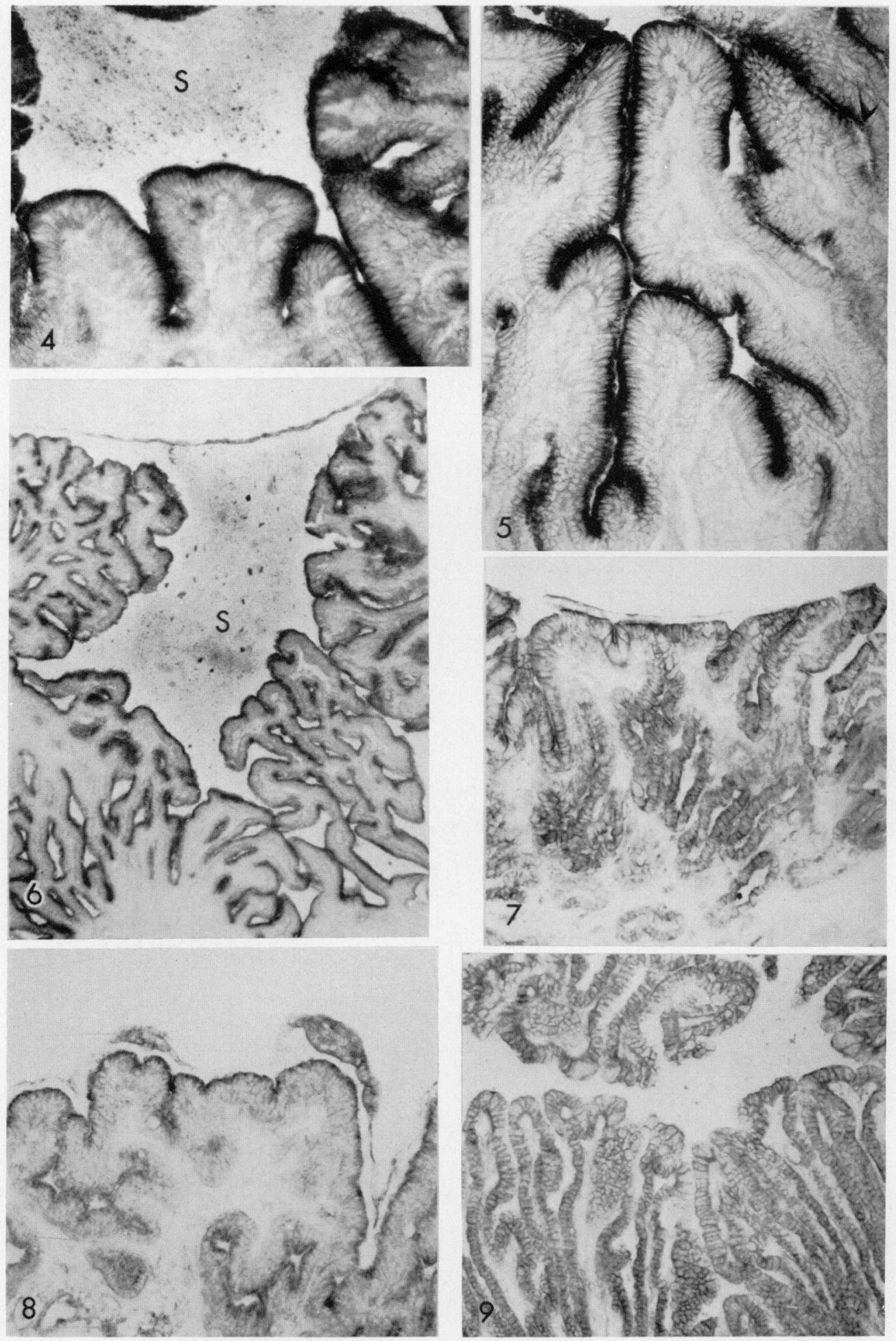

(Facing p. 361) 
both methods, the arylamidase depletion of blastocyst site endometrium from $6 \frac{2}{3}$ days p.c. was confirmed. Before this stage, the activity was uniform over the whole length of the uterus. One of the rabbits killed at 7 days p.c. was exceptional in that there was no diminution of arylamidase activity at any of the blastocyst sites, although the blastocysts were of regular size and appeared morphologically normal.

There are no specialized implantation sites in the rabbit uterus: the selection of certain parts of the uterus for implantation depends only on the number of blastocysts which always become evenly spaced (Böving, 1954). The depletion of arylamidase in the endometrium at the site of implantation does not occur in pseudopregnant uteri or in interblastocyst areas of pregnant uteri up to this stage, and therefore appears to be the result of a direct local effect of the blastocyst on the endometrium. The way by which the blastocyst exerts this effect is now under investigation. Biochemical tests give no evidence for the presence of arylamidase inhibitors in the blastocyst (G. van Hoorn, unpublished). The blastocyst may, however, induce enhanced secretory activity in the surrounding endometrium. Morphological characteristics of secretory processes have been described to involve detachment of apical cytoplasmic protrusions of uterine epithelial cells (Beier, 1971). In the present study, the apical cytoplasm and the protrusions and secretion globules possibly derived from them are shown to be the sites of arylamidase activity. A decline in arylamidase activity in the mesometrial endometrium was correlated with loss of the strong enzyme reaction of the apical cytoplasm, leaving cells looking 'empty' with only low residual activity in the basal and lateral parts. The blastocysts at this time are surrounded by an arylamidase-positive uterine secretion (PI. 1, Fig. 1; Pl. 2, Fig. 6). Enders \& Schlafke (1972) showed that in the ferret the uterine epithelium near the blastocyst becomes depleted of secretory granules at the onset of implantation.

\section{EXPLANATION OF PLATE 2}

Freeze-substituted sections of the rabbit endometrium.

Fic. 4. At 5 days p.c. Note the reaction of the apical part of the epithelium and the secretion granules $(\mathrm{S}) . \times 160$.

Fig. 5. At 6 days p.c. the reaction is confined to the apical part of uterine epithelial cells. $\times 160$.

Fig. 6. The endometrium at the site of the blastocyst, at 6 days p.c. Note the strong reaction of the uterine epithelium (near the blastocyst as well as remote from it) and of uterine secretion (S). The trophoblast (above) is moderately positive. No reaction product is found in the blastocyst cavity. $\times 60$.

Fig. 7. The mesometrial endometrium at the site of the blastocyst, and part of a blastocyst (above) at 62 days p.c. The uterine epithelial cells appear 'empty', and the strong apical reaction is lost, as is typical for the mesometrial part of the blastocyst site in this and the following stages. $\times 100$.

FIG. 8. The site of the blastocyst, the antimesometrial endometrium and the trophoblast (two trophoblastic knobs visible) at 7 days p.c. Note the reduced intensity of the reaction although apices of uterine epithelial cells are still the sites where most of the activity is found, as in antimesometrial endometrium. $\times 100$.

Fig. 9. The endometrium at an interconceptual area at 8 days p.c. There is moderate activity of the uterine epithelial cells and no apical maximum. The cells appear 'empty' (see Fig. 7). $\times 100$. 
Model experiments (Denker, 1975) indicate that the nature of the stimulus provided by the blastocyst does not seem to be mechanical. We are now studying the effects of various chemical stimuli, including steroid hormones possibly secreted by the blastocyst (see Perry et al., 1973; Dickmann et al., 1975).

The biochemical investigations are part of a thesis to be presented at the Fakultät für Biologie, University of Freiburg (West Germany) (GvH). We are indebted to Mrs Sophia El-Deeb for her excellent technical assistance in the performance of histochemical tests. These investigations were supported by the Deutsche Forschungsgemeinschaft (De 181/3).

\section{REFERENCES}

BeIer, H.M. (1971) Die Pseudogravidität des Kaninchens nach Stimulierung mit Choriongonadotropin. Thesis, University of Marburg (Germany).

Bergmeyer, H.U. (1974) Methoden der Enzymatischen Analyse. 3rd edition. Verlag Chemie, Weinheim/ Bergstr.

Böving, B.G. (1954) Blastocyst-uterine relationships. Cold Spring Harb. Symp. quant. Biol. 19, 9-28.

Denker, H.W. (1969) Zur Enzym-Topochemie von Frühentwicklung und Implantation des Kaninchens. Thesis, Med. Fak. University of Marburg (Germany). (Enzym-Topochemie von Frühentwicklung und Implantation des Kaninchens, I-III. Histochemie 25, 256-267, 268-285, and 344-360 (1971).)

Denker, H.W. (1975) Wechselbeziehungen zwischen Blastozyste und Endometrium bei der Implantation: Beeinflussung der endometrialen Aminosäure-Arylamidase-Aktivität durch die Blastozyste. Anat. Anz. Suppl. (in press).

Denker, H.W. \& Stangl, R. (1974) Versuche zur Lokalisierung und Abgrenzung verschiedener Aminosäure-Arylamidasen in Uterus und Blastozyste des Kaninchens. XVII. Acta histochem., Suppl. (in press).

Dickmann, Z., Dey, S.K. \& Gupta, J.S. (1975) Steroidogenesis in rabbit preimplantation embryos. Proc. natn. Acad. Sci. U.S.A. 72, 298-300.

Enders, A.C. \& Sahlafke, S. (1972) Implantation in the ferret: epithelial penetration. Am. J. Anat. $133,291-316$.

Glenner, G.G. (1962) The preservation of peptidase activity localization using $\beta$-naphthylamide substrates. 7. Histochem. Cytochem. 10, 257-258.

Patterson, E.K., Hsiao, S. \& Keppel, A. (1963) Studies on dipeptidases and aminopeptidases. I. Distinction between leucine aminopeptidase and enzymes that hydrolyze L-leucyl-naphthylamide. 7. biol. Chem. 238, 3611-3620.

Pearse, A.G.E. (1972) Histochemistry: Theoretical and Applied, Vol. II. Churchill, London.

Perry, J.S., Heap, R.B. \& Amoroso, E.C. (1973) Steroid hormone production by pig blastocysts. Nature, Lond. 245, 45-47.

Petry, G., Kühnel, W. \& Beier, H.M. (1970) Untersuchungen zur hormonellen Regulation der Präimplantationsphase der Gravidität. I. Histologische, topochemische und biochemische Analysen am normalen Kaninchenuterus. Cytobiologie 2, 1-32.

Schmid, H. (1963) Untersuchungen über Bestimmung und Gehalt der Leucin-Aminopeptidase in Uterus und Vagina der Ratte und Maus. Acta endocr., Copenh. 44, 150-164.

Westley, J. \& Lambeth, J. (1960) Protein determination on the basis of copper-binding capacity. Biochim. biophys. Acta 40, 364. 